\title{
股関節屈曲位における腸腰筋の筋厚測定の検者内 および検者間信頼性
}

\author{
Intra- and Inter-rater Reliabilities of Measurements \\ of Iliopsoas Thickness in Hip Flexion
}

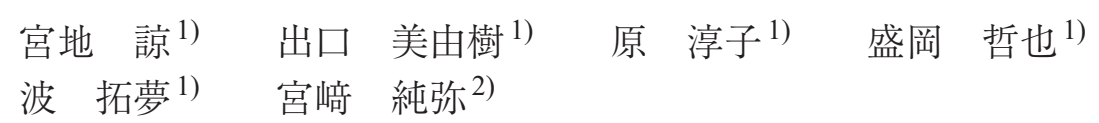

RYo MIYACHI, RPT, PhD ${ }^{1)}$, MiYUKi DEGUCHI, RPT ${ }^{1)}$, JUnKo HARA, RPT ${ }^{1)}$, TETSUYA MORIOKA, RPT ${ }^{1)}$, TAKUMU NAMI, RPT ${ }^{1)}$, JUNYA MIYAZAKI, RPT, $\mathrm{PhD}^{2)}$

${ }^{1)}$ Department of Rehabilitation, Ishikawa-ken Saiseikai Kanazawa Hospital: Ni-13-6 Akatsuchimachi, Kanazawa-shi, Ishikawa 920-0353, Japan TEL+81 76-266-1060 E-mail: ryomiyati@yahoo.co.jp

2) Department of Physical Therapy, Faculty of Health Science, Kyoto Tachibana University

Rigakuryoho Kagaku 34(4): 523-527, 2019. Submitted Mar. 5, 2019. Accepted Apr. 17, 2019.

\begin{abstract}
Purpose] To investigate the intra- and inter-rater reliabilities of measurements of the iliopsoas thickness, and the change in iliopsoas thickness due to hip flexion. [Participants and Methods] The participants were 13 healthy young males. Iliopsoas thickness was measured in hip flexion of 0, 15, 30, 45 and 60 degrees at the center of the groin area using sonography. The intra- and inter-rater reliabilities of measurements of iliopsoas thickness were calculated, and the iliopsoas thickness was compared among the hip flexion positions. [Results] When hip joint flexion was $45^{\circ}$ or less, both the intra- and inter-rater reliabilities of measurements of the iliopsoas thickness were high. Systematic bias was not found at any of the hip flexion angles. The iliopsoas thickness increased with hip flexion. [Conclusion] Highly reproducible data can be obtained by measuring iliopsoas thickness at hip flexion of $45^{\circ}$ or less. However, as the thickness of the iliopsoas thickness changes with hip flexion, making it necessary to consider the hip flexion angle when measuring it.
\end{abstract}

Key words: sonography, iliopsoas, reliability

要旨：〔目的〕股関節屈曲位での腸腰筋筋厚の検者内・検者間信頼性と股関節屈曲に伴う腸腰筋の筋厚変化を調べる こと。【対象と方法〕健常成人男性 13 名を対象とした。超音波画像診断装置を用いて鼠径部中央にて背臥位で股関節 屈曲 $0^{\circ}, 15^{\circ}, 30^{\circ}, 45^{\circ}, 60^{\circ}$ で腸腰筋筋厚を 2 回ずつ計測し, 検者内・検者間の信頼性と股関節屈曲 $0^{\circ}$ と屈曲位の 腸腰筋筋厚変化を解析した。〔結果〕股関節屈曲 $45^{\circ}$ 以下では級内相関係数は高値を示した。系統誤差は全ての股関 節屈曲角度でみられなかった，腸腰筋筋厚は股関節屈曲位が屈曲 $0^{\circ}$ よも高值であった．〔結語〕股関節屈曲 $45^{\circ}$ 以 下での腸腰筋の筋厚測定では信頼性の高いデータが得られる。 また, 股関節屈曲に伴い腸腰筋筋厚が変化するため股 関節屈曲角度を考慮する必要がある.

キーワード : 超音波画像診断装置, 腸腰筋, 信頼性

\footnotetext{
1) 石川県済生会金沢病院 リハビリテーション部：石川県金沢市赤土町二13-6（テ 920-0353）TEL 076-266-1060

2) 京都橘大学 健康科学部 理学療法学科

受付日 2019 年 3 月 5 日 受理日 2019 年 4 月 17 日
} 


\section{I.はじめに}

腸腰筋は単純な股関節の屈曲作用だけではなく股関節 や腰椎の安定性 1,2 , 骨盤位置の調整3) など多くの機能 を有し，筋力などの機能に加えて筋形態に関しても定量 的な評価は重要である。しかしながら腸腰筋は梁層に位 置するため定量的な評価が困難であり，正確かつ簡易的 な評価方法が少ないことが課題である 4,5 .

筋を非侵襲的に評価する方法として超音波画像診断装 置を用いた画像評価があり, 臨床や研究のなかで広く使 用されている 6-8). 磁気共鳴画像診断装置と比較し, 超 音波画像診断装置は簡便かつ任意の肢位での撮像が可能 であることや,リアルタイムで情報を得られるという利 点がある，その一方で，プローブ操作の技術的な習熟が 必要であることや 9), 筋厚評価が筋量の計測には有用で あるが筋活動を反映しない点 ${ }^{10)}$ が欠点として挙げられ る. 筋厚が筋活動を反映しない理由に, 筋・筋膜の伸張 性 ${ }^{10)}$ や収縮様式などいくつかの要因があるが，その一 つとして測定条件が一般化されていないことがある。

超音波画像による評価はプローブの関倸上多くの場合 に抢いて筋全体の評価が困難であり，一定区間を抽出し た評価となる。そのため超音波画像を用いた報告では関 節角度の变化や筋収縮が生じた際の筋全体の形態情報を 捉えた報告はないに等しい，測定部位によって関節角度 の変化や筋収縮に伴う筋厚変化の増減やその程度が異な ることが予想されるが, 各筋で筋厚変化が筋活動などを 反映しやすい測定部位や関節角度などの測定条件は明ら かにされていない，したがって筋厚評価を臨床応用する うえで, 様々な測定条件での筋厚変化に関する基礎情報 を検討することが重要であり，その測定条件での信頼性 についても併せて検討する必要があると考えられる。

腸腰筋に関して磁気共鳴画像診断装置と超音波画像診 断装置にて測定した筋厚と差がなく, 超音波画像診断装 置に打ける検者間の信頼性が高いことがMendis ら 9)に より示されている，しかし，股関節屈曲 $0^{\circ}$ のみの測定 信頼性の報告であり, 股関節屈曲 $0^{\circ}$ だけでなく関節可 動域制限により股関節屈曲位で撮像せざるを得ないこと や，スクワットなど股関節屈曲位での動作中の活動の評 価を求められることが想定される。股関節屈曲角度が増 加することでプローブの操作性や腸腰筋形態が股関節伸 展位と異なることが予想されるが, どの程度の股関節屈 曲角度まで信頼性がある計測結果が得られるのかという ことや, 股関節屈曲に伴う腸腰筋の筋厚（以下，腸腰筋 厚）変化の基礎情報については報告されていない．

そこで本研究の目的は, 超音波画像診断装置を使用し， 測定条件のなかで特に信頼性が低くなることが予想され る股関節屈曲位での腸腰筋厚の検者内抢よび検者間の信 頼性について検討することとした，さらに，股関節屈曲 角度の増加に伴い, 非収縮時に打いても腸腰筋厚が増加
することが予測されるため腸腰筋厚の変化についても検 討することとした.

\section{II. 対象と方法}

\section{1. 対象}

下肢や脊柱に関節障害などの既往がなく，日常生活に 影響する疼痛がない健常成人男性 13 名 $(28.0 \pm 4.9$ 歳, $173.1 \pm 5.1 \mathrm{~cm}, 69.8 \pm 5.2 \mathrm{~kg}$ : 平均 \pm 標準偏差 $)$ を 対象とした。本研究は石川県済生会金沢病院倫理委員会 の承認を得て実施した（受付番号：平成 30 年度申請第 22 号). 被験者には事前に研究の目的抢よび内容につい て, 得られたデー夕を研究以外には使用しないこと, お よび個人情報の漏洩に注意することについて十分に説明 し，参加の同意署名を得たうえで実施した。

2. 方法

測定肢位は安静背臥位とし, 角度調整が可能な台上に 両側下肢を置くことで股関節屈曲角度を調整した。股関 節屈曲角度は屈曲 $0^{\circ}, 15^{\circ}, 30^{\circ}, 45^{\circ}, 60^{\circ}$ に設定し, 利き脚（ボールを蹴る方の下肢）にて 2 回ずつ測定した. 腸腰筋の撮像は超音波画像診断装置 (LOGIQe, GEへ ルスケアジャパン社製）を使用し， B モードにてリニア プローブ $(10 \mathrm{MHz})$ を用いて行った，測定部位は鼠径 部中央（ASIS と䎵骨結合を結んだ線の中点）にて腸腰 筋を確認後, 筋収縮を行い腸腰筋を同定した。検者ごと に各角度での測定を行う際に、プローブ位置を一定とす るために鼠径部中央にあらかじめマーキングを施し，そ の上にプローブを接触して腸腰筋の短軸像を撮像した。

検者内信頼性の検討では, 検者 $\mathrm{A}$ (臨床経験年数 9 年) が初回測定日の 7 日後に同様の方法で 2 回目の撮像を 行った。検者間信頼性の検討では検者は 2 名とし, 検者 A が撮像し終えた後, 一定時間を执いて同様の方法にて 検者 B（臨床経験年数 3 年）が撮像を行った。 な押, 検 者 $\mathrm{A}$ の測定結果について検者 Bがわからない状況とし たうえで検者 $\mathrm{B}$ が測定を実施した，取得した超音波画 像診断装置の画像から解析プログラム ImageJ（アメリ 力国立衛生研究所製）にて筋膜の境界を基準に腸腰筋の 最大長を計測した. 2 回の測定值の平均值を算出し腸腰 筋厚の值とした。

統計解析は SPSS 19 (IBM SPSS Statistics, IBM 社製) を使用した. Shapiro-Wilk 検定にてデータの正規性を確 認した。相対的信頼性は級内相関係数（Intraclass correlation coefficient：以下, ICC) を用い, 検者 A の 初回測定值と 2 回目測定值の検者内信頼性 ICC (1.2) 抢よび検者 $\mathrm{A}$ の初回測定值と検者 $\mathrm{B}$ 測定値の検者間信 頼性 ICC（2.2）を算出した，また，絶対的信頼性を確 認するためにBland-Altman 分析を行い，系統誤差を確

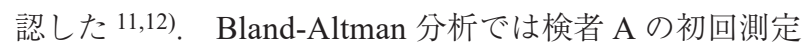


值と検者 $\mathrm{A}$ の 2 回目測定值および検者 $\mathrm{B}$ の測定值の差 を $\mathrm{y}$ 軸, 2 つの測定值の平均值を $\mathrm{x}$ 軸とする散布図を作 成した，可視的な判断たけでなく，統計学的に固定誤差 の有無を判断するために 2 つの測定值の差の平均值の $95 \%$ 信頼区間を算出し，区間内に0を含まない場合に 固定誤差が存在すると判断した. 比例誤差の有無の判断 には，相関の有意性の検定を行った， $\mathrm{n}$ を標本数， $\mathrm{r}$ を 2 つの測定值の差と 2 つの測定值の平均值の相関係数と し, $\mathrm{t}=\mathrm{r} \sqrt{\mathrm{n}-2 /\left(1-\mathrm{r}^{2}\right)}$ の式により $\mathrm{t}$ 值を算出した。 $\mathrm{t}$ 值 が自由度 $\mathrm{n}-2$, 有意水準 $5 \%$ の $\mathrm{t}$ 值よりも大きければ有

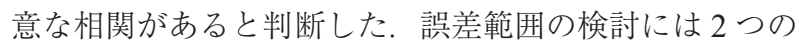
測定值の差の標準偏差を用いた最小可検変化量の $95 \%$ 信頼区間（2つの測定值の差の標準偏差 $\times 1.96 ）$ を算出 し使用した。股関節屈曲 $0^{\circ}$ と股関節屈曲位の腸腰筋厚 の比較は Dunnett 検定を適用した。
III. 結 果

各股関節角度における腸腰筋厚の検者内の ICC の值 と Bland-Altman 分析の結果を表 1 に，検者間での ICC の值と Bland-Altman 分析の結果を表 2 に, 腸腰筋厚の 平均値 \pm 標準偏差を表 3 に示した。 ICC (1.2) は各股 関節屈曲角度で $0.74 \sim 0.93$ であり股関節屈曲 $60^{\circ}$ が 0.74 と最も低值を示した（表 1)． ICC（2.2）は 0.87〜0.92 であり股関節屈曲 $15^{\circ}$ が 0.87 と最も低值であった (表 2). Bland-Altman 分析の結果，検者内の測定值の 差の $95 \%$ 信頼区間は $0^{\circ}$ は $-0.13 \sim 0.13, \quad 15^{\circ}$ は -0.09 $0.08,30^{\circ}$ は $-0.07 \sim 0.13,45^{\circ}$ は $-0.10 \sim 0.19,60^{\circ}$ は -0.17〜0.15であった（表 1 ).

検者間の測定值の差の $95 \%$ 信頼区間は $0^{\circ}$ は $-0.02 \sim$ $0.18, \quad 15^{\circ}$ は $-0.11 \sim 0.15, \quad 30^{\circ}$ は $-0.08 \sim 0.15, \quad 45^{\circ}$ は

表 1 各股関節屈曲角度における腸腰筋筋厚の検者内の相対的および絶対的信頼性

\begin{tabular}{lccccc}
\hline \multicolumn{1}{c}{ 股関節屈曲角度 $\left({ }^{\circ}\right)$} & 0 & 15 & 30 & 45 & 60 \\
\hline 検者内再現性 ICC $(1.2)$ & 0.86 & 0.93 & 0.90 & 0.84 & 0.74 \\
$95 \%$ 信頼区間 & $0.56 \sim 0.96$ & $0.79 \sim 0.98$ & $0.70 \sim 0.97$ & $0.48 \sim 0.95$ & $0.18 \sim 0.92$ \\
\hline 測定值の差の 95\%信頼区間 & $-0.13 \sim 0.13$ & $-0.09 \sim 0.08$ & $-0.07 \sim 0.13$ & $-0.10 \sim 0.19$ & $-0.17 \sim 0.15$ \\
固定誤差の有無 & 無 & 無 & 無 & 無 & 無 \\
\hline 相関の有意性 & 0.14 & 1.79 & 0.12 & 1.95 & 1.95 \\
比例誤差の有無 & 無 & 無 & 無 & 無 & 無 \\
\hline 最小可検変化量の 95\%信頼区間 $(\mathrm{cm})$ & 0.42 & 0.29 & 0.33 & 0.46 & 0.52 \\
\hline
\end{tabular}

ICC : Intraclass correlation coefficient.

表 2 各股関節屈曲角度における腸腰筋筋厚の検者間の相対的および絶対的信頼性

\begin{tabular}{lccccc}
\hline \multicolumn{1}{c}{ 股関節屈曲角度 $\left({ }^{\circ}\right)$} & 0 & 15 & 30 & 45 & 60 \\
\hline 検者間再現性 ICC $(2.2)$ & 0.90 & 0.87 & 0.92 & 0.88 & 0.90 \\
95\%信頼区間 & $0.66 \sim 0.97$ & $0.57 \sim 0.96$ & $0.74 \sim 0.97$ & $0.61 \sim 0.96$ & $0.69 \sim 0.97$ \\
\hline 測定值の差の 95\%信頼区間 & $-0.02 \sim 0.18$ & $-0.11 \sim 0.15$ & $-0.08 \sim 0.15$ & $-0.08 \sim 0.13$ & $-0.08 \sim 0.16$ \\
固定誤差の有無 & 無 & 無 & 無 & 無 & 無 \\
\hline 相関の有意性 & 0.33 & 0.01 & 0.15 & 0.71 & 0.16 \\
比例誤差の有無 & 無 & 無 & 無 & 無 & 無 \\
\hline 最小可検変化量の 95\%信頼区間 $(\mathrm{cm})$ & 0.33 & 0.34 & 0.37 & 0.34 & 0.39 \\
\hline
\end{tabular}

ICC : Intraclass correlation coefficient.

表 3 各股関節屈曲角度における腸腰筋筋厚

\begin{tabular}{lccccc}
\hline 股関節屈曲角度 $\left({ }^{\circ}\right)$ & 0 & 15 & 30 & 45 & 60 \\
\hline 検者 $\mathrm{A}$ (初回) 腸腰筋筋厚 $(\mathrm{cm})$ & $2.65 \pm 0.29$ & $2.79 \pm 0.31^{*}$ & $2.92 \pm 0.27^{\dagger}$ & $3.02 \pm 0.28^{\dagger}$ & $3.11 \pm 0.34^{\dagger}$ \\
検者 $\mathrm{A}(2$ 回目) 腸腰筋筋厚 $(\mathrm{cm})$ & $2.65 \pm 0.30$ & $2.80 \pm 0.25^{*}$ & $2.95 \pm 0.28^{\dagger}$ & $3.06 \pm 0.34^{\dagger}$ & $3.09 \pm 0.22^{\dagger}$ \\
検者 B 腸腰笳笳厚 $(\mathrm{cm})$ & $2.72 \pm 0.28$ & $2.84 \pm 0.31^{*}$ & $2.94 \pm 0.27^{\dagger}$ & $3.05 \pm 0.24^{\dagger}$ & $3.15 \pm 0.33^{\dagger}$ \\
\hline
\end{tabular}

平均值 \pm 標準偏差. * : 股関節屈曲 $0^{\circ}$ と比較し有意差あり $(\mathrm{p}<0.05), \dagger:$ 股関節屈曲 $0^{\circ}$ と比較し有意差あり $(\mathrm{p}<0.01)$. 
$-0.08 \sim 0.13, \quad 60^{\circ}$ は $-0.08 \sim 0.16$ であった（表 2 ）。相 関の有意性検定は検者内信頼性では $0^{\circ}$ は $0.14,15^{\circ}$ は 1.79, $30^{\circ}$ は $0.12,45^{\circ}$ は $1.95,60^{\circ}$ は 1.95 であった（表 1). 検者間においては $0^{\circ}$ は $0.33,15^{\circ}$ は $0.01,30^{\circ}$ は 0.15 , $45^{\circ}$ は $0.71,60^{\circ}$ は 0.16 であった（表 2 ). 最小可検変 化量の $95 \%$ 信頼区間は検者内の測定では $0^{\circ}$ は $0.42 \mathrm{~cm}$, $15^{\circ}$ は $0.29 \mathrm{~cm}, 30^{\circ}$ は $0.33 \mathrm{~cm}, 45^{\circ}$ は $0.46 \mathrm{~cm}, 60^{\circ}$ は $0.52 \mathrm{~cm}$ であった（表 1 )。検者間の測定では $0^{\circ}$ は 0.33 $\mathrm{cm}, 15^{\circ}$ は $0.34 \mathrm{~cm}, 30^{\circ}$ は $0.37 \mathrm{~cm}, 45^{\circ}$ は $0.34 \mathrm{~cm}$, $60^{\circ}$ は $0.39 \mathrm{~cm}$ であった（表 2$)$ ）股関節屈曲 $0^{\circ}$ と股関 節屈曲位での腸腰筋厚の比較では股関節屈曲 $15^{\circ}$ は $\mathrm{p}<$ 0.05 で股関節屈曲 $15^{\circ}$ が屈曲 $0^{\circ}$ よりも有意に高值であっ た。股関節屈曲 $30^{\circ}, 45^{\circ}, 60^{\circ}$ は $\mathrm{p}<0.01$ で屈曲 $0^{\circ}$ と 比較して有意に高值であった（表 3 ）.

\section{IV. 考 察}

本研究は超音波画像診断装置を使用した鼠径部中央に おける測定においてどの程度の股関節屈曲角度まで腸腰 筋厚測定值が検者内および検者間の信頼性が得られるの かということと, 股関節屈曲角度の増加に伴う腸腰筋厚 の変化を検討した.

Landis ら 13) は, ICC に関して 0.61〜0.80を substantial, 0.81〜1.00を almost perfectとしている. Portney ら 14) は 0.75 以上を good reliability としているが, 臨床応用 するうえで 0.90 を超えることを推奨している.しかし ながら，それらには明確な根拠はなく一般的には 0.70 以上であれば信頼性は高く研究上の問題もないとされて いる15)。本研究結果ではICC（1.2）に関しては股関節 屈曲 $60^{\circ}$ 以外はLandis の段階付けにおいてはalmost perfectに位置し，腸腰筋厚測定の検者内信頼性が高い ことが示唆される。股関節屈曲 $60^{\circ}$ は ICC が 0.74 と 0.70 以上であるものの $95 \%$ 信頼区間下限值は 0.18 と低值で あり, 股関節屈曲 $45^{\circ}$ 以下と比較すると信頼性は劣ると 言わざるを得ない，その理由として股関節屈曲 $60^{\circ}$ では 股関節屈曲 $45^{\circ}$ 以下と比べて骨盤と大腿骨が接近しプ ローブ操作が困難となることや，股関節屈曲に伴う腸腰 筋形態や位置の変化により画像上の筋の境界が不明瞭と なることが信頼性に影響を及ぼしたと考えられる。一方， ICC（2.2）に関してはいずれの角度においても0.81を 上回り almost perfectであった。したがって検者間信頼 性においては股関節屈曲 $60^{\circ}$ までは腸腰筋厚測定の相対 的信頼性は担保されることが示唆される。

絶対的信頼性の検討においては検者内・検者間ともに 2 つの測定值の差の平均值の $95 \%$ 信頼区間内に 0 を含 み, 固定誤差がみられないと判断される。比例誤差に関 して，算出した $\mathrm{t}$ 值は検者内・検者間ともに自由度 11 , 有意水準 5\%の $\mathrm{t}$ 值である 2.20 よりも小さく, 比例誤差 はみられないと判断される，以上から検者内では股関節
屈曲 $45^{\circ}$ 以下では腸腰筋厚はともに相対的・絶対的とも に信頼性の高いデータが得られ，腸腰筋を評価するうえ での指標として使用できると考えられる. 固定誤差と比 例誤差といった系統誤差が認められない場合, 偶然誤差 のなかで測定誤差を検討する方法として最小可検変化量 の $95 \%$ 信頼区間の使用がしばしば用いられる ${ }^{11)}$. $2 つ$ の測定值の変化量が測定誤差によるものであるという限 界域を示すものであり，算出された数值以下であれば測 定誤差と判断され，数值よりも大きい值であれば実際に 筋厚の差があったと捉えられるとされている ${ }^{11)}$ ，その ため今回得られて最小可検変化量の $95 \%$ 信頼区間の值 は腸腰筋の筋厚の変化を捉えるうえで重要であると考え られる。

腸腰筋厚については股関節屈曲角度の増加に伴い高い 值を示した. Kinugasa ら 16) は筋が一定の容積を有する ため筋の伸張により筋横断面積が減少することを報告し ており，本研究では逆に股関節を屈曲することで腸腰筋 が短縮位となり筋横断面積が増加したことが考えられ る.このことから股関節屈曲位での撮像時には各測定条 件での股関節屈曲角度の統一や腸腰筋の短縮による筋厚 の増加を差し引いた解釈を行うなどの肢位の違いに伴う 筋厚変化への考慮が必要であることが示唆される.

本研究結果は臨床での股関節屈曲位での腸腰筋の活動 に対するフィードバックや腸腰筋厚を指標とした研究な どの一助となると考えられる。しかし，Pappasら 17)は 収縮の強さによって筋形態の変化が異なることを示して おり，筋活動の指標として筋厚を研究・臨床応用するた めには測定部位や角度条件だけでなく収縮の強さや収縮 様式, 筋・筋膜の伸張性などの数多く条件の考慮が必要 であり，まだ課題は多いと考えられる，加えて本研究の 限界として，プローブが腸腰筋に対して垂直となってい るかの評価が困難であることや，筋厚のみの評価であり， 筋の断面積を直接的に評価していないことが挙げられ る. 股関節屈曲に伴う腸腰筋厚の増加だけでなく, 三次 元的な形態や位置の変化が測定信頼性に影響を及ぼすこ とも想定されるため, 磁気共鳴画像診断装置などを用い た三次元的な情報との比較も重要であると考えられる. また，筋線維に対して垂直に横断した断面積である生理 学的横断面積と比較して, 筋全体の長軸に対して垂直に 横断した解剖学的横断面積が直接的に筋力に影響しにく いことが報告されており ${ }^{18)}$ ，筋厚の測定に関しても筋 全体の長軸に対して垂直な筋厚のみの評価ではなく, 羽 状角を考慮した生理学的横断面積の測定が必要となるこ とが考えられる。 また, 股関節屈曲筋力などの筋機能を 評価した際の腸腰筋の形態情報との関係についても今後 検討していく必要がある.

本研究では鼠径部中央での超音波画像による測定にお いて股関節屈曲角度 $0 \sim 45$ ○では検者内および検者間と もに信頼性の高い值が得られることが示唆された。 また 
股関節屈曲に伴い腸腰筋厚は増加するため測定の際には 関節角度の規定などの考慮が必要であることが考えら れる。

なお, 本研究の一部は, 第 6 回日本運動器理学療法学 会で発表した。

利益相反 本研究に関連して，筆頭著者に開示すべき利 益相反はない.

\section{引用文献}

1) Lewis CL, Sahrmann SA, Moran DW: Anterior hip joint force increases with hip extension, decreased gluteal force, or decreased iliopsoas force. J Biomech, 2007, 40: 3725-3731.

2) $\mathrm{Hu} H$, Meijer OG, van Dieën JH, et al.: Is the psoas a hip flexor in the active straight leg raise? Eur Spine J, 2011, 20: 759-765.

3) Andersson E, Oddsson L, Grundström H, et al.: The role of the psoas and iliacus muscles for stability and movement of the lumbar spine, pelvis and hip. Scand J Med Sci Sports, 1995, 5: $10-16$.

4) Balius R, Pedret C, Blasi M, et al.: Sonographic evaluation of the distal iliopsoas tendon using a new approach. J Ultrasound Med, 2014, 33: 2021-2030.

5) Jiroumaru T, Kurihara T, Isaka T: Establishment of a recording method for surface electromyography in the iliopsoas muscle. J Electromyogr Kinesiol, 2014, 24: 445-451.

6) Kirchmair L, Entner T, Kapral S, et al.: Ultrasound guidance for the psoas compartment block: an imaging study. Anesth Analg, 2002, 94: 706-710.

7) 福元喜啓, 池添冬芽, 山田陽介-他: 超音波画像診断装置 を用いた骨格筋の量的・質的評価. 理学療法学, 2015, 42:
65-71.

8) Dupont AC, Sauerbrei EE, Fenton PV, et al.: Real-time sonography to estimate muscle thickness: comparison with MRI and CT. J Clin Ultrasound, 2001, 29: 230-236.

9) Mendis MD, Wilson SJ, Stanton W, et al.: Validity of real-time ultrasound imaging to measure anterior hip muscle size: a comparison with magnetic resonance imaging. J Orthop Sports Phys Ther, 2010, 40: 577-581.

10) Whittaker JL, Stokes M: Ultrasound imaging and muscle function. J Orthop Sports Phys Ther, 2011, 41: 572-580.

11) 下井俊典：評価の絶対信頼性. 理学療法科学, 2011, 26: 451-461.

12）勝又泰貴, 竹井 仁，林 洋暁・他：超音波を用いた筋膜 移動距離と筋硬度測定の検者内および検者間信頼性. 理学 療法科学, 2017, 32, 215-220.

13) Landis JR, Koch GG: The measurement of observer agreement for categorical data. Biometrics, 1977, 33: 159-174.

14) Portney LG, Watkins MP: Foundations of clinical research: applications to practice. Appleton \& Lange, New York, 1993, pp560-567.

15) 網本 和, 高倉保幸 (編) : <理学療法NAVI > 臨床の“疑 問”を“研究”に変える 臨床研究 first stage. 医学書院, 東京, 2017, pp202-207.

16) Kinugasa R, Hodgson JA, Edgerton VR, et al.: Asymmetric deformation of contracting human gastrocnemius muscle. $\mathrm{J}$ Appl Physiol 1985, 2012, 112: 463-470.

17) Pappas GP, Asakawa DS, Delp SL, et al.: Nonuniform shortening in the biceps brachii during elbow flexion. J Appl Physiol 1985, 2002, 92: 2381-2389.

18) Fukunaga T, Roy RR, Shellock FG, et al.: Physiological cross-sectional area of human leg muscles based on magnetic resonance imaging. J Orthop Res, 1992, 10: 928-934. 